\title{
Analysis of the bearing capacity of unbound granular mixtures with rubber particles from scrap tyres when used as sub-ballast
}

\author{
C. Hidalgo-Signes ${ }^{\mathrm{a}} \bowtie$, P. Martínez-Fernández ${ }^{\mathrm{b}}, \mathrm{J}_{\text {. Garzón-Roca }}^{\mathrm{a}}$, R. Insa-Franco ${ }^{\mathrm{b}}$
}

a. Department of Geotechnical and Geological Engineering, Universitat Politècnica de València (UPV). (Valencia, Spain) b. Department of Transport Engineering and Infrastructure, Universitat Politècnica de València (UPV). (Valencia, Spain) $\triangle$ chidalgo@trr.upv.es

Received 9 December 2015 Accepted 24 May 2016 Available on line 2 November 2016

\begin{abstract}
Scrap tyres are a problematic waste material. As a method for recycling large quantities of rubber from scrap tyres, this paper analyses the use of unbound granular mixtures with varying percentages of rubber particles as sub-ballast in railway lines. Bearing capacity for such mixtures is studied in laboratory and field tests using static and dynamic plate load tests, as well as cyclic triaxial tests. It is found that adding rubber increases permanent and resilient strain and that none of the mixtures suffer plastic creep after 2.5 million cycles. Considering the usual bearing capacity requirements, the optimum rubber content is $2.5 \%$ (by weight). This percentage increases resistance to degradation while ensuring sufficient bearing capacity.
\end{abstract}

KEYWORDS: Waste treatment; Aggregate; Modulus of Elasticity; Cycles; Mechanical properties

Citation/Citar como: Hidalgo-Signes, C.; Martínez-Fernández, P.; Garzón-Roca, J.; Insa-Franco, R. (2016) Analysis of the bearing capacity of unbound granular mixtures with rubber particles from scrap tyres when used as sub-ballast. Mater. Construcc. 66 [324], e105. http://dx.doi.org/10.3989/mc.2016.11515

RESUMEN: Análisis de la capacidad de soporte de mezclas de material granular con partículas de caucho procedentes de neumáticos fuera de uso para su uso como subbalasto. Los neumáticos fuera de uso son un material de desecho problemático. Para poder reutilizarlos en grandes cantidades, el artículo se centra en el análisis de mezclas granulares sin ligante con un porcentaje variables de partículas de caucho, y su uso como capa de subbalasto ferroviario. La capacidad de soporte de dichas mezclas se estudia mediante ensayos de laboratorio y de campo (ensayos de placa de carga estática y dinámica, y ensayos triaxiales cíclicos). Se evalúa la influencia del contenido de caucho en cada caso. Se ha observado que, a mayor contenido en caucho, se incrementa la deformación permanente y resiliente, y que ninguna de las mezclas experimenta fluencia plástica tras 2,5 millones de ciclos de carga. Considerando los requisitos habituales de capacidad de soporte, el contenido óptimo de caucho es 2,5\% en términos de peso. Este porcentaje incrementa la resistencia a la degradación al tiempo que asegura una capacidad de soporte suficiente.

PALABRAS CLAVE: Tratamiento de residuos; Árido; Módulo Elástico; Ciclos; Propiedades mecánicas

Copyright: (C) 2016 CSIC. This is an open-access article distributed under the terms of the Creative Commons Attribution License (CC BY) Spain 3.0. 


\section{INTRODUCTION}

Scrap tyres are a problematic waste material as they are produced in large quantities and their disposal is difficult. One of the most promising options is to use rubber shreds from scrap tyres as raw material for the construction sector, particularly for roads and railway lines. The shreds are either mixed with other materials or used as a standalone component to form some of the earthwork layers below the infrastructure.

This option has been studied in some detail in recent decades, especially for roads (1-4), and there are some promising results regarding long-term stability. However, the use of tyre shreds in the construction of new railway lines has been little studied and such studies are mostly limited to bituminous mixtures (5). Unbound mixtures of mineral aggregates and rubber particles have so far been neglected - apart from a noteworthy experiment that added rubber to ballast (6) and found that a $10 \%$ addition of rubber (by volume) to the ballast layer reduces particle breakage and improves energy dissipation.

These experiments show that the use of crumbled scrap tyres in earthworks offers a potential method for disposing of such material and can improve certain properties of the unmixed aggregate. However, the scarcity of works devoted to this topic, at least in the context of railways, also reveals a lack of knowledge regarding the behaviour of unbound aggregate-rubber mixtures and shows the need for more detailed studies.

This is particularly true for the sub-ballast layer, which plays a vital role as a foundation for the superstructure (i.e. rails, sleepers, and ballast) and carries the vehicle loads to the ground. To the authors' knowledge, the addition of rubber particles to this layer has not been assessed in detail. As the sub-ballast layer is a key element of the track and its performance dramatically affects the reliability and durability of the whole infrastructure, an in-depth investigation must be made prior to substituting the traditional material with a new mixture of mineral aggregate and rubber.

In a previous investigation, the authors carried out a comprehensive set of standardised laboratory and field tests (7) to fully characterise unbound granular mixtures with rubber particles that were intended to substitute traditional sub-ballast layers in railway tracks (see Figure 1). Results from that study show that adding up to 5\% (by weight) of rubber particles to an unbound granular soil produced a mixture with improved resistance to degradation and that the bearing capacity is within the limits required by Spanish and international regulations (PF-7 (8) and UIC 719R (9) respectively).

The results from (7) indicate the potential for adding rubber particles to the sub-ballast layer. Nevertheless, certain key aspects were barely assessed during that initial investigation; namely, the long-term bearing capacity; behaviour with cyclic loads; and the influence of moisture. Moreover, the reliability of field tests presents another problem. Many characteristics required by national and international regulations for the sub-ballast layer are measured using standardised laboratory and field tests, and while the former are performed under carefully controlled conditions, the latter may be affected by several factors that compromise reliability (10). Bearing capacity is usually assessed with just the static bearing plate test (BS 1377-9 (11)). However, this common test may be affected by many in situ factors (e.g. variations in moisture) that may lead to an overestimation of the bearing capacity (12).

Taking into account these issues regarding field tests and the results from the authors' previous study (7), this paper aims to further assess the reliability of such mixtures by further describing their behaviour and focusing on short and long-term bearing capacity. These fundamental aspects of sub-ballast layers in railway infrastructures were not taken into account in the previous study. Close attention is also paid to the mixture behaviour with cyclic loads and optimum moisture content, as well as the relationship between laboratory and field tests.

The objectives are, firstly, to study in detail the short-term bearing capacity of the mixtures using static bearing plate tests in the laboratory; as well as testing the long-term bearing capacity using a combination of dynamic cyclic and static tests that measure structural stability. Secondly, the paper aims to address the field test drawbacks mentioned above by carrying out laboratory and field tests and studying the relationship between the former (obtained under more controlled conditions) and the latter (which is the test most commonly required by regulations). It is interesting to mention that these types of correlations

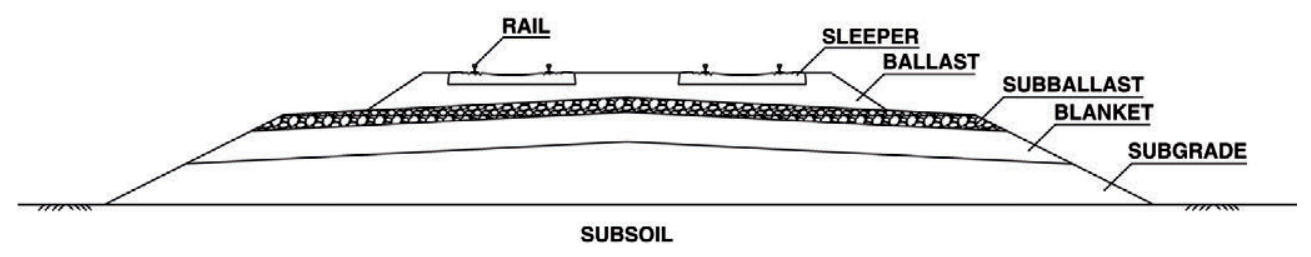

FIGURE 1. Railway track cross section. 
have been studied in the past, mostly focusing on field tests such as light falling weight deflectometer (LFWD) vs. plate load test (PLT) (13-14) while field vs. lab test correlation is less studied.

The final objective is to determine the optimum content of rubber particles that ensures a bearing capacity that complies with regulations, guarantees long-term stability and preserves the advantages of mixing such particles found in previous works (7).

\section{MATERIALS AND METHODS}

\subsection{Material selection and sampling}

The mixtures studied in this paper were made of two main materials: mineral aggregate and rubber particles from scrap tyres. The aggregate was a well graded crushed dolomite rock provided by an aggregate treatment company from Alicante (Spain) that meets all the requirements set by Spanish (8) and international standards (9). This material was chosen as it is representative of the natural aggregates used in south-eastern Spain for building roads and railways. Rubber particles were provided by a Spanish scrap tyre company (SIGNUS) in three different fractions: a maximum size of $20 \mathrm{~mm}$; a maximum size of $2 \mathrm{~mm}$; and a maximum size of $1 \mathrm{~mm}$ (hereafter NFU 20, NFU 2 and NFU 1 respectively). This material was chosen as the most common and economic option offered by the supplier.

Once received in the laboratory, the materials were stored, treated, and sampled according to ASTM D75/D75M-09 (15). It is worth noting that since both the aggregate and the NFU 20 are retained on the $19 \mathrm{~mm}$ sieve in a proportion of less than $30 \%$ (by mass), and more than $20 \%$ is retained on the $10 \mathrm{~mm}$ sieve, gradation corrections are not required in accordance with ASTM D-1557 (16).

Figure 2 shows the samples prepared for the rubber-aggregate mixtures. Mixing was carried out by weight as this is common practice on works in situ. All mixtures were prepared using a laboratory planetary mixer, first mixing the aggregate and the rubber particles for two minutes and then adding water and mixing for an additional minute. All mixtures were prepared with the same aggregate, sampled, and dried during $24 \mathrm{~h}$ at $105^{\circ} \mathrm{C}$, with only the rubber content being varied. Irrespective of the total amount of rubber particles added to each mixture, the proportion of each rubber fraction was $40 \%$ NFU 20, 40\% NFU 2 and 20\% NFU 1.

Four mixtures were prepared with varying percentages of rubber, namely $1,2.5,5$ and $10 \%$ by weight. For a more detailed description of the materials used, as well as a thorough characterisation of their basic properties see Hidalgo et al. (7).

Laboratory and field tests were made in accordance with international standards. Table 1 shows the tests, whose purpose is explained in detail in the following sections.

\subsection{Laboratory tests}

\subsubsection{Compaction test}

Compaction tests were conducted to obtain the maximum dry density and optimum moisture content for each studied mixture. Samples were placed in moulds (152.4 mm diameter) and dynamically compacted using a $4.535 \mathrm{~kg}$ mass falling from a

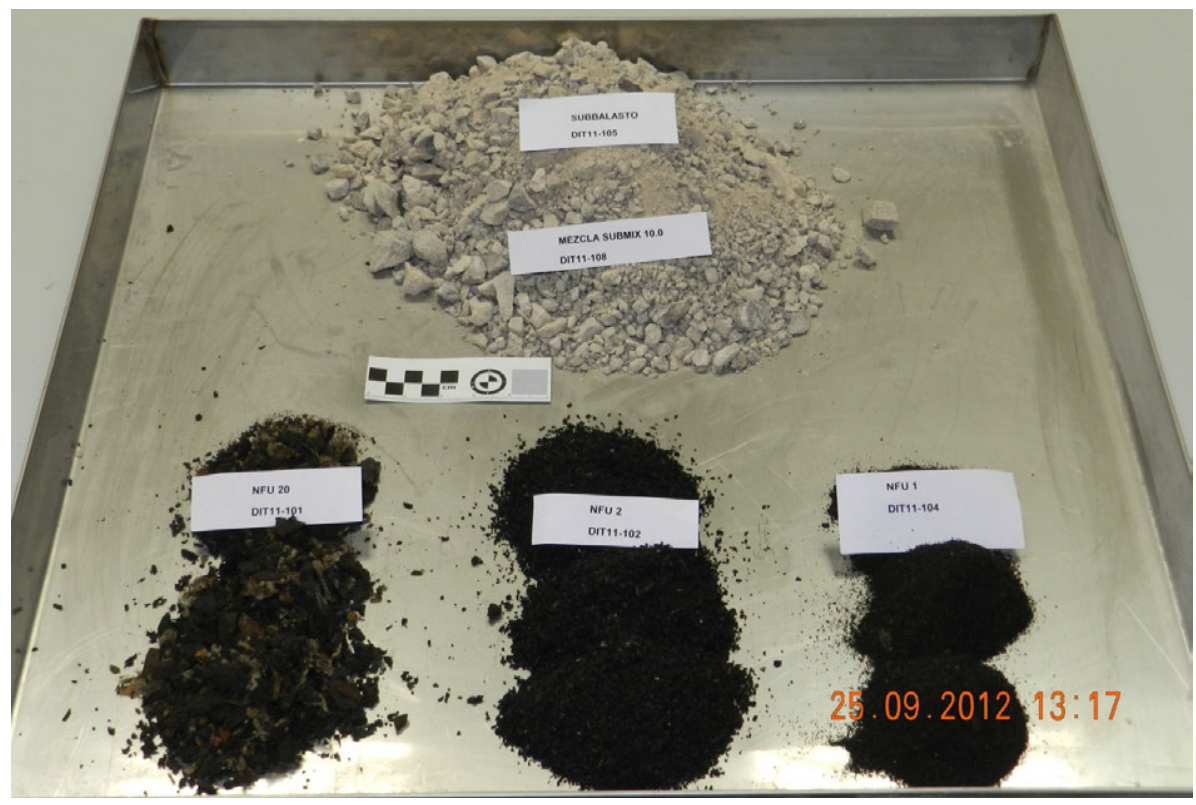

Figure 2. Sampled materials. 
TABLE 1. Laboratory and field tests

\begin{tabular}{|c|c|c|c|c|}
\hline Laboratory test & Standard & Aggregate & Rubber & Mixture \\
\hline Modified Proctor compaction & ASTM D1557 & $\mathrm{X}$ & $\mathrm{X}$ & $\mathrm{X}$ \\
\hline Laboratory static bearing plate $(\varnothing 75 \mathrm{~mm})$ & Adapted from BS 1377-9 & $\mathrm{X}$ & & $\mathrm{X}$ \\
\hline Laboratory cyclic bearing plate test (Ø $75 \mathrm{~mm})$ & Ad hoc & $\mathrm{X}$ & & $\mathrm{X}$ \\
\hline Cyclic load triaxial test & UNE-EN 13286-7 & $\mathrm{X}$ & & $\mathrm{X}$ \\
\hline Hydraulic conductivity: falling head permeability test & PF-7 Annex 3 & $\mathrm{X}$ & $\mathrm{X}$ & $\mathrm{X}$ \\
\hline Field test & Standard & Base ground & Platform & Sub-ballast \\
\hline Density 'in situ' (radioactive isotopes) & $\begin{array}{l}\text { ASTM D3017 } \\
\text { ASTM D2922 }\end{array}$ & $\mathrm{X}$ & $\mathrm{X}$ & $\mathrm{X}$ \\
\hline Static bearing plate $(\varnothing 300 \mathrm{~mm})$ & BS $1377-9$ & & $\mathrm{X}$ & $\mathrm{X}$ \\
\hline LFWD (Ø 300 mm) & ASTM D4694 & & $X$ & $X$ \\
\hline
\end{tabular}

height of $457 \mathrm{~mm}$. Five layers were laid, each compacted with 56 impacts in accordance with method C described in ASTM D-1557 (16).

\subsubsection{Staticldynamic bearing plate tests}

Once both maximum dry density and optimum moisture content were determined, bearing plate tests were conducted in the laboratory, as adapted from a common field test $(8,9)$. The objective was to study the bearing capacity of the mixtures and how it is affected by the addition of rubber particles. The tests were performed in the laboratory so as to improve control testing conditions and compare the results with those from the traditional field test.

A mould (300x300x200 mm) was used to prepare the samples. The mould was placed over a concrete block $(600 \times 600 \times 200 \mathrm{~mm})$ to ensure a proper compaction. Samples were prepared by laying and compacting the material in three layers (using a vibratory plate) until maximum dry density was reached. To ensure homogenous moisture content, each sample was then left to rest for 24 hours before further testing. To perform the bearing plate test, a circular steel plate with a diameter of $75 \mathrm{~mm}$ was used, hence ensuring that the ratio between the plate diameter and the sample maximum particle size was less than four.

Loads were applied in accordance with BS 1377-9 (11) in four steps (all values in $\mathrm{MPa}$ ): (i) 1 st loading step: $0.00,0.08,0.16,0.24,0.32,0.40$, $0.45,0.50$; (ii) 1 st unloading step: $0.25,0.12,0.00$; (iii) 2nd loading step: $0.08,0.16,0.24,0.32,0.40$; and (iv) 2nd unloading step: $0.25,0.12,0.08,0.00$. After the first loading step, the first static deformation modulus $\left(\mathrm{E}_{\mathrm{v} 1}\right)$ was obtained, and the second static deformation modulus $\left(\mathrm{E}_{\mathrm{v} 2}\right)$ was obtained after the second loading step.

The specific purpose of this static test was to assess how the addition of rubber particles affects the bearing capacity of the mixtures, measured using the compressibility moduli $\left(\mathrm{E}_{\mathrm{v} 1}\right.$ and $\left.\mathrm{E}_{\mathrm{v} 2}\right)$ of each mixture, as well as the pattern (unmixed aggregate).
Once the static bearing plate test was completed, the second round of tests was performed, consisting of a combination of dynamic and static bearing plate tests. The purpose of this second set was to evaluate the long-term behaviour of the mixtures at the end of their life cycle, and more precisely to assess whether they experience creep in the long term. A dynamic variation of the static bearing plate test was devised to simulate some 20 years of railway traffic. Four new samples were prepared independently of those used in the first testing campaign. The dynamic test was performed at a controlled stress level of $100 \mathrm{kPa}$ (which is similar to stress levels measured in sub-ballast layers, according to Melis (17)) with a frequency of $10 \mathrm{~Hz}$, using a servo-hydraulic press (Instrom 8874) and applying up to 2.5 million cycles (Figure 3 ). The test was intended to reflect a typical high-speed train service such as the Spanish AVE 112 series, whose usual configuration consists of 21 wheelsets and 14 daily services (the usual schedule on the Madrid-Valencia high-speed line). This test represents approximately 20 years of service. The static bearing plate test was carried out immediately after the dynamic test was completed. Moisture content was measured for all samples after each test.

\subsubsection{Cyclic triaxial test}

A cyclic load triaxial test was carried out for all the samples to further examine the issue of longterm behaviour. The main purpose of this test was to define the plastic creep limit for each mixture, in accordance with the Shakedown theory as explained by Werkmeister et al. (18) and Cerni et al. (19). This theory establishes that permanent strain tends to stabilise after a given number of loading cycles when low magnitude cyclic loads are applied to an aggregate. However, if the magnitude of the loads is high enough, permanent strain increases dramatically and may cause a gradual failure. Therefore, there is a critical stress value that marks the border between stability and instability, and the cyclic triaxial test 
enables this limit to be identified. Once known, we can determine whether the expected loads that a sub-ballast layer will experience during its life cycle will be under the limit. If so, failure would only be expected after many load cycles (19).

All the samples were submitted to a consolidated drained (CD) cyclic triaxial test to measure behaviour under permanent strain, following the procedure in UNE-EN 13286-7 (20). Each sample was submitted to four confining pressures $\left(\sigma_{3}\right)$ : namely; $20,50,70$ and $100 \mathrm{kPa}$. The test starts with the lowest deviation stress, which is then gradually increased

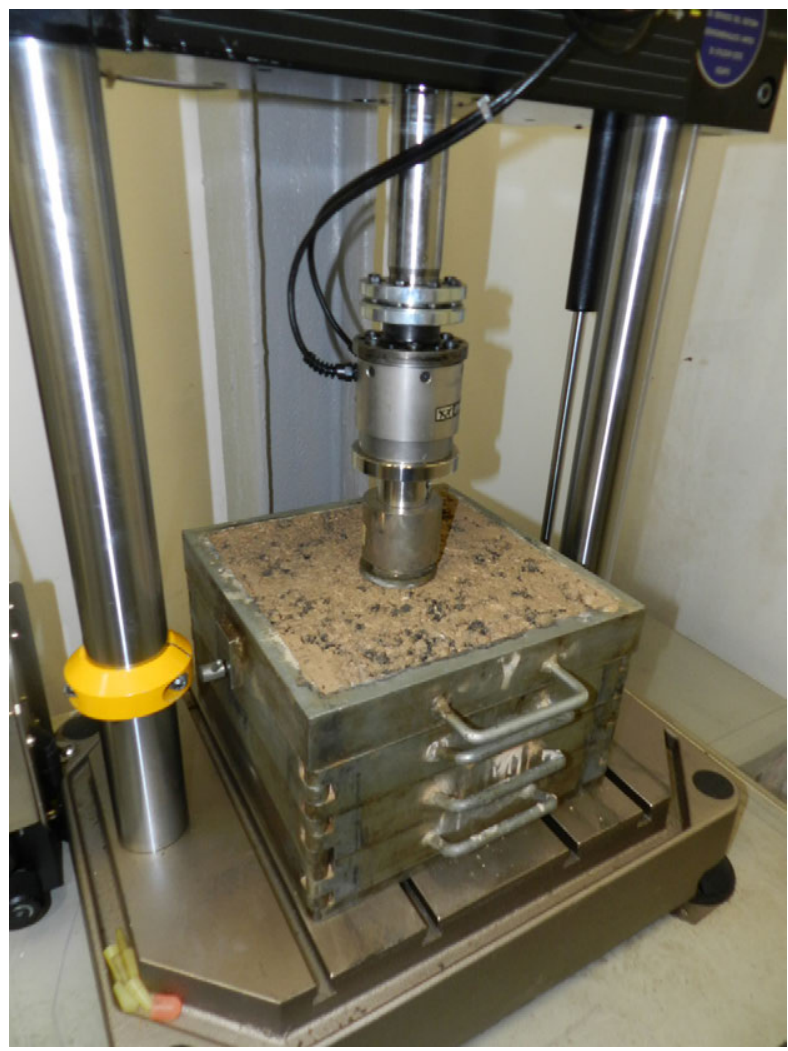

Figure 3. Dynamic test. until failure. The plastic creep limit is defined by the stress combination that yields a difference between the 3000 and 5000 permanent strain cycles of at least 400 ustrain units.

A repeated load triaxial apparatus (Cooper NU-14 model) was used, equipped with a force cell inside the triaxial chamber to measure axial stress and linear variable differential transformers (LVDT) outside the chamber to measure axial strain. For each mixture (including the pattern), four cylindrical samples were made with a diameter of $150 \mathrm{~mm}$ and a height of $200 \mathrm{~mm}$. All the samples were at an optimum moisture level and 100\% compacted (Modified Proctor). They were protected after compaction with $0.6 \mathrm{~mm}$ thick latex membranes. Table 2 shows the combinations of cyclic axial stress $\left(\sigma_{1}\right)$ and confining pressure $\left(\sigma_{3}\right)$ used. The cyclic load was applied using a sine wave with a frequency of $10 \mathrm{~Hz}$.

\subsubsection{Hydraulic conductivity test}

The influence of rubber particles on the hydraulic conductivity of the mixtures was assessed using a falling head permeability test, carried out according to the procedure found in PF-7 annex 3 (8). This is particularly important as regulation requires that the sub-ballast hydraulic conductivity be less than $1 \mathrm{E}-6 \mathrm{~m} / \mathrm{s}$, so as to guarantee that water filtered through the ballast and onto the sub-ballast be easily washed away and does not reach the underlying platform layers with the subsequent risk to embankment stability.

Figure 4 shows the layout of the test. All samples were compacted in a modified CBR mould up to $100 \%$ of the Modified Proctor energy.

\subsection{Field tests}

An experimental railway platform was built to assess the results obtained in the laboratory and study the correlation between those results and the usual field tests carried out in situ. The platform was

TABLE 2. Stress levels during the multi-stage cyclic triaxial test

\begin{tabular}{|c|c|c|c|c|c|}
\hline \multirow{2}{*}{$\begin{array}{l}\text { Confining stress } \sigma_{3} \\
\mathbf{k P a}\end{array}$} & \multirow{2}{*}{$\begin{array}{c}\text { Minimum } \\
\text { deviator stress } \sigma_{\mathrm{d}} \\
\mathbf{k P a} \\
\end{array}$} & \multicolumn{4}{|c|}{ Stress ratio $\sigma_{\mathrm{d}} / \sigma_{3}$} \\
\hline & & Sub-ballast & Mix 1.0 & Mix 2.5 & Mix 5.0 \\
\hline 20 & 5 & $\begin{array}{l}1 ; 2 ; 3 ; 4 ; 5 ; 6 ; 7 ; 8 ; 9 ; 10 \\
11 ; 12 ; 13 ; 14 ; 15 ; 16 ; 17 \\
18 ; 19 ; 20 ; 21\end{array}$ & $\begin{array}{l}1 ; 2 ; 3 ; 4 ; 5 ; 6 ; 7 ; 8 ; \\
9 ; 10 ; 11\end{array}$ & $\begin{array}{l}1 ; 2 ; 3 ; 4 ; 5 ; 6 \\
7 ; 8\end{array}$ & $1 ; 2 ; 3 ; 4 ; 5 ; 6$ \\
\hline 50 & 5 & $\begin{array}{l}1 ; 1.5 ; 2 ; 2.5 ; 3 ; 4 ; 5 ; 6 ; \\
7 ; 8 ; 9 ; 10 ; 11 ; 12 ; 13 ; 14 \\
15 ; 16 ; 17 ; 18\end{array}$ & $\begin{array}{l}1 ; 1.5 ; 2 ; 2.5 ; 3 ; 4 ; 5 ; 6 \\
7 ; 8 ; 9\end{array}$ & $\begin{array}{l}1 ; 1.5 ; 2 ; 2.5 ; 3 ; 4 \\
5 ; 6 ; 7\end{array}$ & $1 ; 1.5 ; 2 ; 2.5 ; 3 ; 4$ \\
\hline 70 & 5 & $\begin{array}{l}1 ; 1.5 ; 2 ; 2.5 ; 3 ; 4 ; 5 ; 6 ; 7 ; \\
8 ; 9 ; 10\end{array}$ & $\begin{array}{l}1 ; 1.5 ; 2 ; 2.5 ; 3 ; 4 ; 5 ; 6 \\
7 ; 8 ; 9\end{array}$ & $\begin{array}{l}1 ; 1.5 ; 2 ; 2.5 ; 3 \\
4 ; 5 ; 6\end{array}$ & $1 ; 1.5 ; 2 ; 2.5 ; 3 ; 4$ \\
\hline 150 & 5 & $\begin{array}{l}1 ; 1.5 ; 2 ; 2.5 ; 3 ; 4 ; 5 ; 6 \\
7 ; 8 ; 9\end{array}$ & $1 ; 1.5 ; 2 ; 2.5 ; 3 ; 4 ; 5 ; 6 ; 7$ & $\begin{array}{l}1 ; 1.5 ; 2 ; 2.5 ; 3 \\
4 ; 5 ; 6\end{array}$ & $1 ; 1.5 ; 2 ; 2.5 ; 3 ; 4$ \\
\hline
\end{tabular}




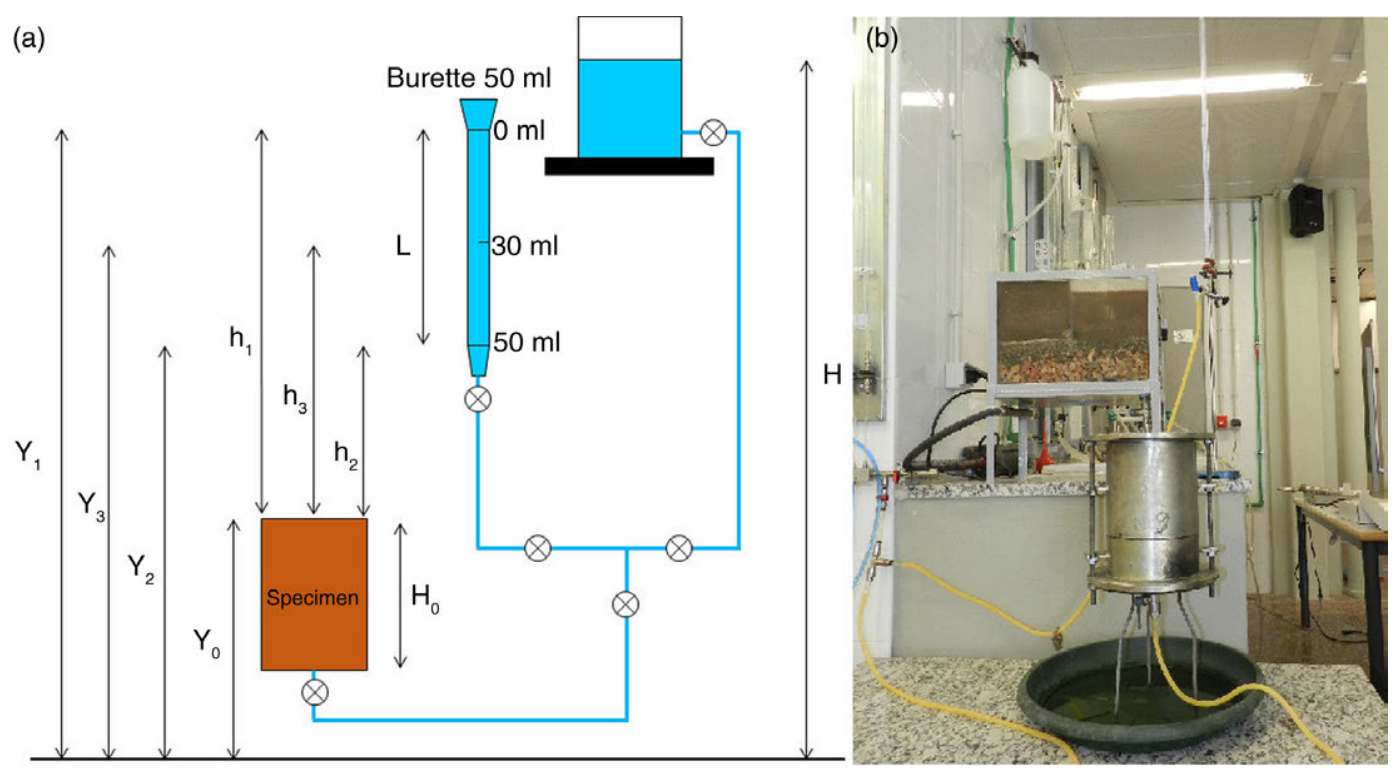

FIGURE 4. Falling head permeability test: a) test setup b) permeameter.

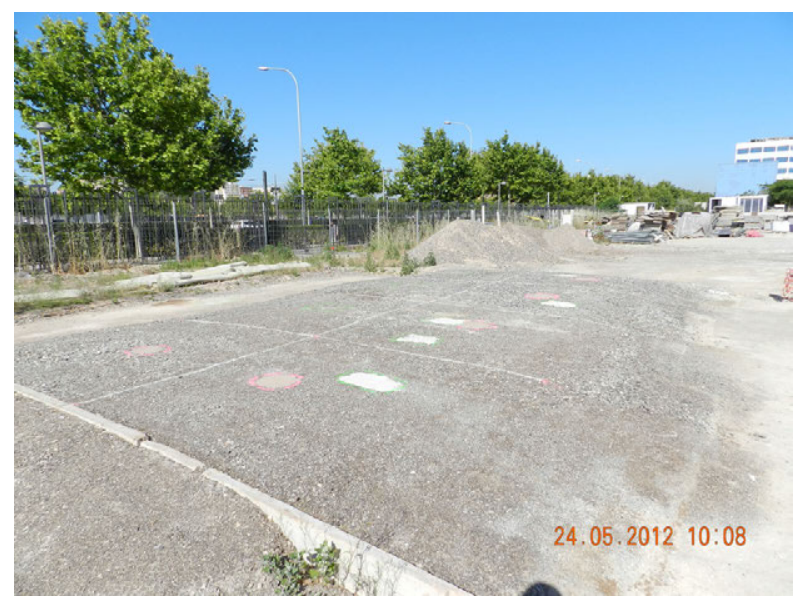

FIGURE 5. Experimental railway platform.

10 metres long and 10 metres wide (Figure 5) and consisted of two layers: a $35 \mathrm{~cm}$ thick layer made of selected granular material (platform) covered by a second $30 \mathrm{~cm}$ layer (sub-ballast).

The underlying layer was common for the whole platform, and the sub-ballast layer was divided into four $2.5 \mathrm{~m}$ long sections: one made from traditional sub-ballast material and the others from various aggregate-rubber mixtures $(1,2.5$ and $5 \%$ by weight, respectively). All layers were compacted (100\% Modified Proctor) and moisture content was controlled using radioactive isotopes. For a more detailed explanation of the experimental platform configuration see Hidalgo et al. (7).

Bearing plate tests were carried out in accordance with BS 1377-9 (11) using a $300 \mathrm{~mm}$ diameter plate and with the same loading steps defined for the laboratory tests. Additionally, LFWD tests were

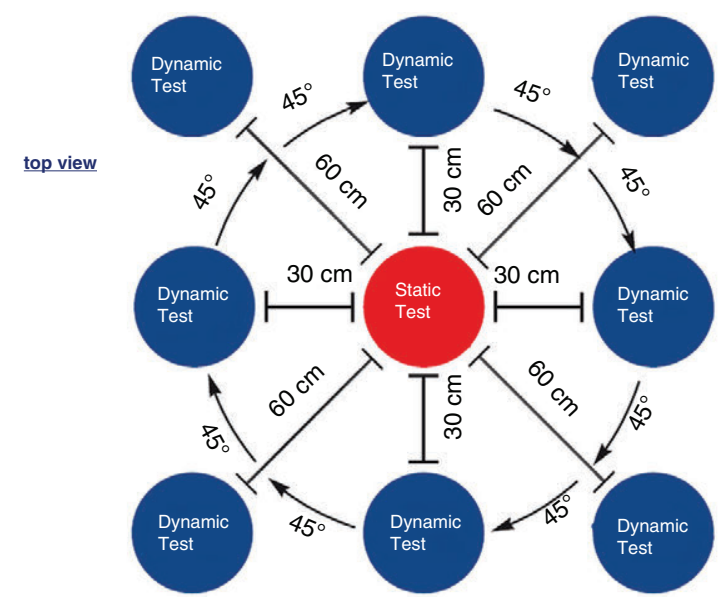

cut

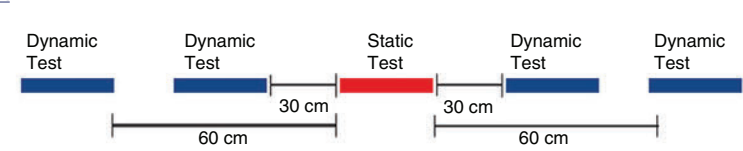

Figure 6. Experimental layout for field tests.

performed in accordance with ASTM E2835 (21) and UNE 103807-2 (22). The configuration for both tests is shown in Figure 6.

It should be noted that the bearing plate test is currently the only test required by Spanish and international regulations to control sub-ballast placing during the construction of railway lines. This test delivers a static deformation modulus $\left(\mathrm{E}_{\mathrm{v} 1}\right.$ and $\left.\mathrm{E}_{\mathrm{v} 2}\right)$, while the LFWD yields a complementary dynamic deflection modulus $\left(\mathrm{E}_{\mathrm{vd}}\right)$. By performing both tests, it is possible to assess their relationship and make comparisons with laboratory results. 


\section{RESULTS AND DISCUSSION}

\subsection{Laboratory results}

\subsubsection{Gradation size}

All the mixtures were designed to ensure a low void ratio as a means to achieve a good bearing capacity and little deformation. Figure 7 shows the gradation curves for all mixtures, as well as for the unmixed aggregate. It is clear from the figure that the gradation of all mixtures is very similar to that of the pattern material, and all the mixtures are well within the limits of the gradation curves required by PF-7.

\subsubsection{Compaction test}

Figure 8 shows the results obtained from the compaction test, which aims to determine the maximum dry density and optimum moisture content for the four mixtures, as well as the unmixed sub-ballast used as a pattern material. As the figure shows, the dry unit weight reduces as the rubber content increases. Conversely, the optimum moisture content remains almost constant due to the differing absorption rates of the two mineral fractions (i.e. fine and coarse). In the short term, the added water is absorbed by the finest aggregate fraction despite the rubber content (23).
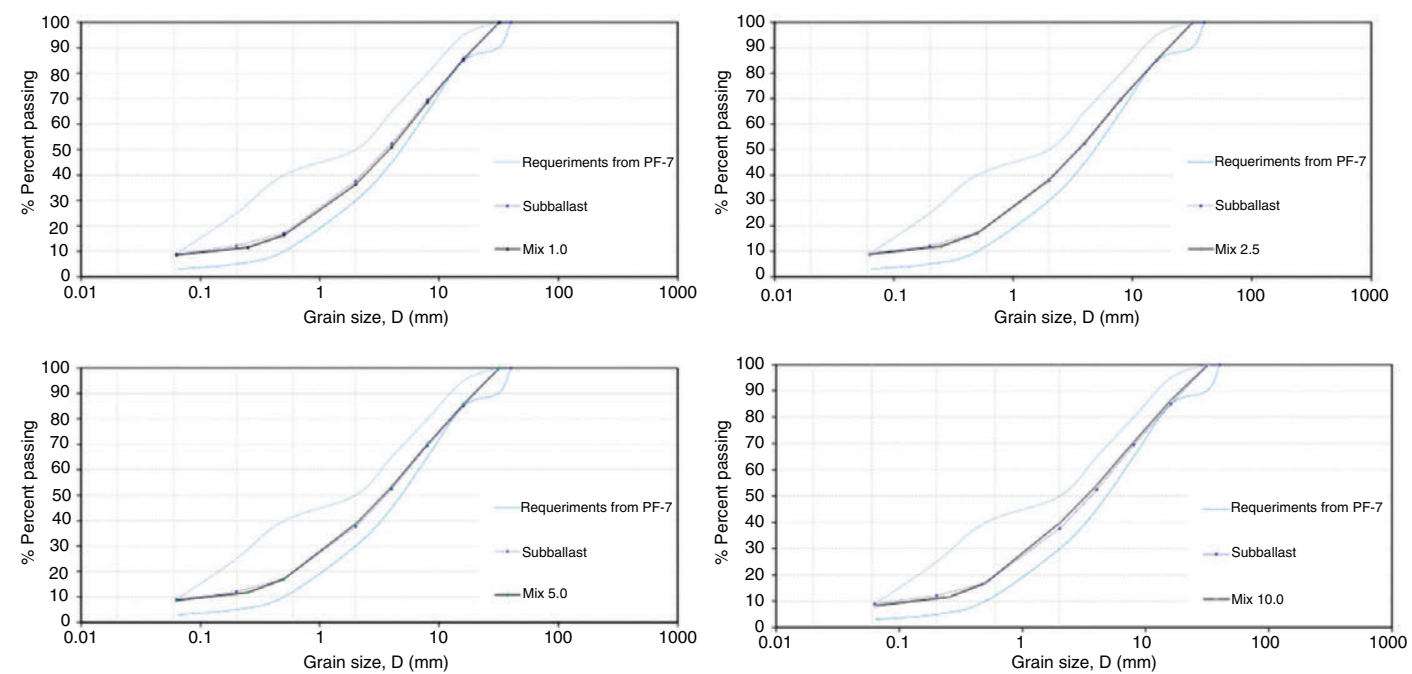

FIGURE 7. Gradation curves. Mixtures vs. pattern aggregate.

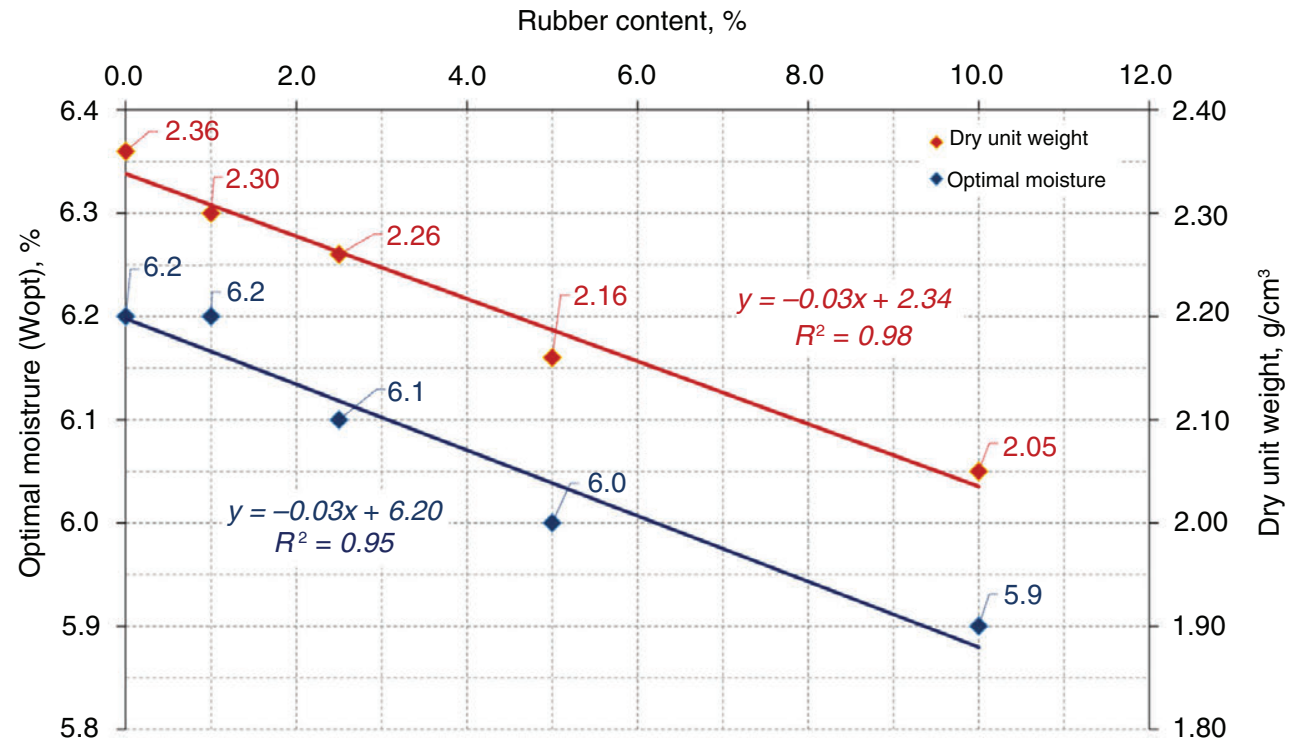

FIGURE 8. Dry unit weight and optimal moisture content vs rubber content. 
Considering these small differences in the optimum moisture content, all mixtures subjected to the bearing plate tests were compacted with the same moisture content $(6.2 \%)$ in order to ensure a wetof-optimum compaction (which is the best option for granular materials). Table 3 enables a further analysis of the relationship between moisture and rubber content and shows the results obtained for moisture content in the samples submitted to bearing plate tests.

Those mixtures with higher rubber content show lower moisture content after being tested because their higher compressibility and porosity facilitates drainage. Although porosity is independent of particle size (24), it is modified (increased in this case) by the change in the particle packing due to the addition of rubber. Another noteworthy result is that water loss was slightly higher after the dynamic and static tests were completed because these tests take longer to carry out than the standalone bearing plate test.

\subsubsection{Staticldynamic bearing plate test}

Table 4 shows the results obtained from the standalone bearing plate test and the dynamic/static test combination.

The results show that both the compressibility moduli $\left(\mathrm{E}_{\mathrm{v} 1}\right.$ and $\left.\mathrm{E}_{\mathrm{v} 2}\right)$ decrease with the addition of rubber particles. However, after the dynamic test (2.5 million cycles) the parameter $\mathrm{E}_{\mathrm{v} 1}$ clearly increases when compared to the materials tested without previous alterations. The same trend is observed for the
$\mathrm{E}_{\mathrm{v} 2}$ parameter, especially when the rubber content is greater than $2.5 \%$. This growth in bearing capacity is because the rubber-aggregate mixtures show greater permanent strains than the unmixed aggregate, and so their density increases after cyclic loading (post-compaction) with the subsequent increase in bearing capacity. This result shows that dynamic loading modifies the packing between aggregate and rubber particles, as previously explained.

This is further observed in the $\mathrm{E}_{\mathrm{v} 2} / \mathrm{E}_{\mathrm{v} 1}$ ratio, which is required to be below 2.2 (8). Although the addition of rubber tends to reduce the $\mathrm{E}_{\mathrm{v} 2} / \mathrm{E}_{\mathrm{v} 1}$ ratio, the requirement is only fulfilled when the mixtures have previously been dynamically compacted. The samples tested under the static bearing plate test are far from the threshold (although the addition of rubber tends to reduce the $\mathrm{K}$ ratio). This is partly because the $\mathrm{E}_{\mathrm{v} 2} / \mathrm{E}_{\mathrm{v} 1}$ ratio is very sensitive to the compaction conditions of the upper layer - and so the first loading step modulus tends to be lower than expected. This is one of the main criticisms made regarding the standard test as explained by Santiago et al. (12).

Figure 9 shows the deformation achieved in the dynamic test (which represents approximately 20 years of service). Note that the $2.5 \%$ mixture was only tested during 1.6 million cycles due to a power shortage during testing, but the trend for all the mixtures after 100000 cycles is very similar and so we do not expect the $2.5 \%$ mixture to behave differently at those levels.

As the figure shows, permanent strain tends to stabilise after 100000 cycles for all the mixtures tested. This result is similar to that observed

TABLE 3. Dry unit weight and moisture content before and after bearing plate tests

\begin{tabular}{lccccc}
\hline Standalone bearing plate test & Sub-ballast & Mix 1.0 & Mix 2.5 & Mix 5.0 & Mix 10.0 \\
\hline Dry unit weight $\left(\mathrm{g} / \mathrm{cm}^{3}\right)$ & 2.35 & 2.28 & 2.24 & 2.18 & 2.01 \\
Initial moisture content (\%) & 6.20 & 6.20 & 6.20 & 6.20 & 6.20 \\
Final moisture content (\%) & 5.20 & 5.30 & 4.90 & 4.90 & 4.90 \\
\hline Dynamic test + bearing plate test & Sub-ballast & Mix 1.0 & Mix 2.5 & Mix 5.0 & Mix 10.0 \\
\hline Dry unit weight $\left(\mathrm{g} / \mathrm{cm}^{3}\right)$ & 2.36 & 2.28 & 2.24 & 2.19 & 2.01 \\
Initial moisture content (\%) & 6.20 & 6.20 & 6.20 & 6.20 & 6.20 \\
Final moisture content (\%) & 4.90 & 4.90 & 4.80 & 4.70 & 4.70 \\
\hline
\end{tabular}

TABLE 4. Bearing plate test results

\begin{tabular}{lccccc}
\hline Standalone bearing plate test & Sub-ballast & Mix 1.0 & Mix 2.5 & Mix 5.0 & Mix 10.0 \\
\hline $\mathrm{E}_{\mathrm{v} 1}(\mathrm{MPa})$ & 29 & 30 & 31 & 14 & 6 \\
$\mathrm{E}_{\mathrm{v} 2}(\mathrm{MPa})$ & 225 & 180 & 129 & 75 & 20 \\
Ratio K $=\mathrm{E}_{\mathrm{v} 2} / \mathrm{E}_{\mathrm{v} 1}$ & 7.76 & 6.00 & 4.16 & 5.36 & 3.33 \\
\hline Dynamic test + bearing plate test & Sub-ballast & Mix 1.0 & Mix 2.5 & Mix 5.0 & Mix 10.0 \\
\hline $\mathrm{E}_{\mathrm{v} 1}(\mathrm{MPa})$ & 101 & 98 & 83 & 47 & 37 \\
$\mathrm{E}_{\mathrm{v} 2}(\mathrm{MPa})$ & 209 & 176 & 153 & 116 & 68 \\
Ratio K $=\mathrm{E}_{\mathrm{v} 2} / \mathrm{E}_{\mathrm{v} 1}$ & 2.07 & 1.80 & 1.84 & 2.47 & 1.84 \\
\hline
\end{tabular}


by Werkmeister et al. (18) for common unbound granular materials. The $10 \%$ mixture experiences a much higher deformation $\left(\varepsilon_{\mathrm{p}} \approx 2.5 \%\right)$ than the other mixtures, particularly when compared to the pattern material $\left(\varepsilon_{\mathrm{p}} \approx 0.7 \%\right)$, while the other mixtures are within the same order of magnitude $\left(\varepsilon_{\mathrm{p}}\right.$ between $0.8 \%$ and $1.1 \%$ ). Therefore, the $10 \%$ mixture does not seem suitable for sub-ballast due to its high deformation, which is far above the values usually observed in railway tracks (25). This result is also in agreement with previous research (7). Focusing on the behaviour of the other mixtures, the figure shows that all suffer a small progressive collapse between 4000 and 20000 cycles, which increases in magnitude as the rubber content increases. Nevertheless, the permanent deformation reaches a stable level in all cases after 100000 cycles. It is worth noting that none of the mixtures experience plastic creep.

Figure 10 shows the stress-strain curve obtained from the bearing plate test (with and without previous dynamic tests). It shows that the cyclic loading significantly reduces the settlement, hence increasing both compressibility moduli and reducing the $\mathrm{K}$ ratio below the required 2.2 threshold. Additionally, it is clear that in both cases the elastic recovery after the second loading step is higher than that of the first step. This is because the behaviour of the sample after the first step is almost entirely resilient.

The relationship between the compressibility moduli $\left(\mathrm{E}_{\mathrm{v} 1}\right.$ and $\left.\mathrm{E}_{\mathrm{v} 2}\right)$ and the content of rubber

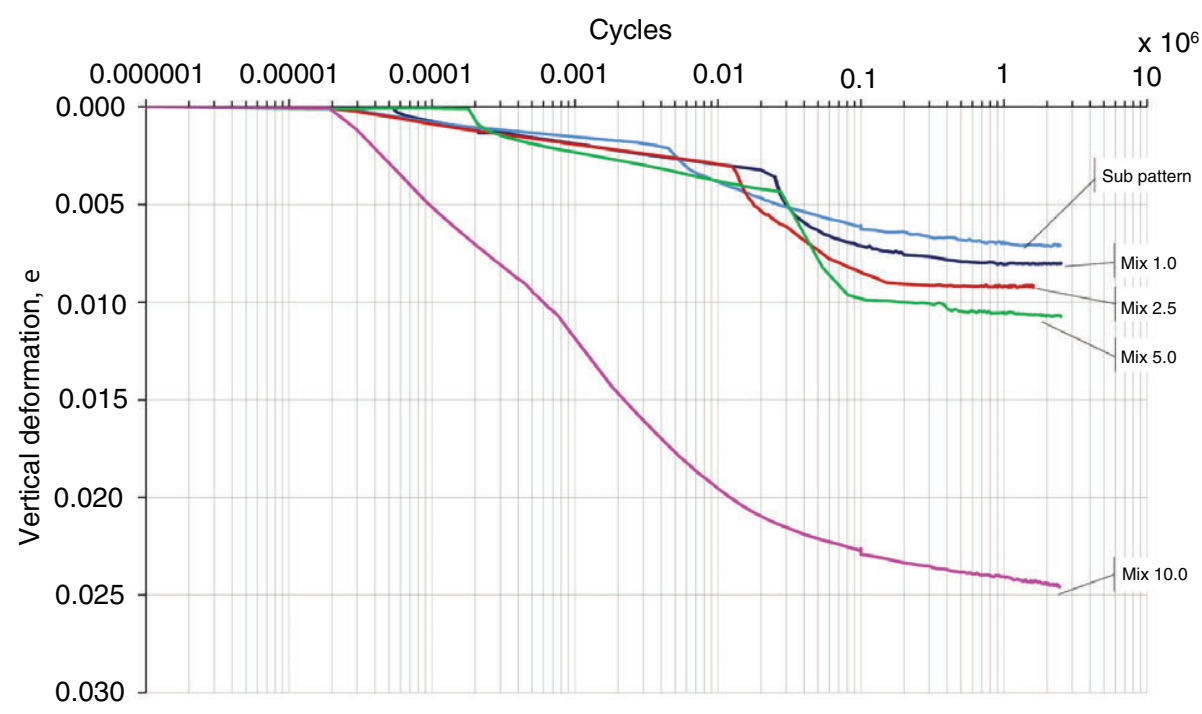

FiguRE 9. Permanent vertical deformation obtained from the dynamic load plate test.

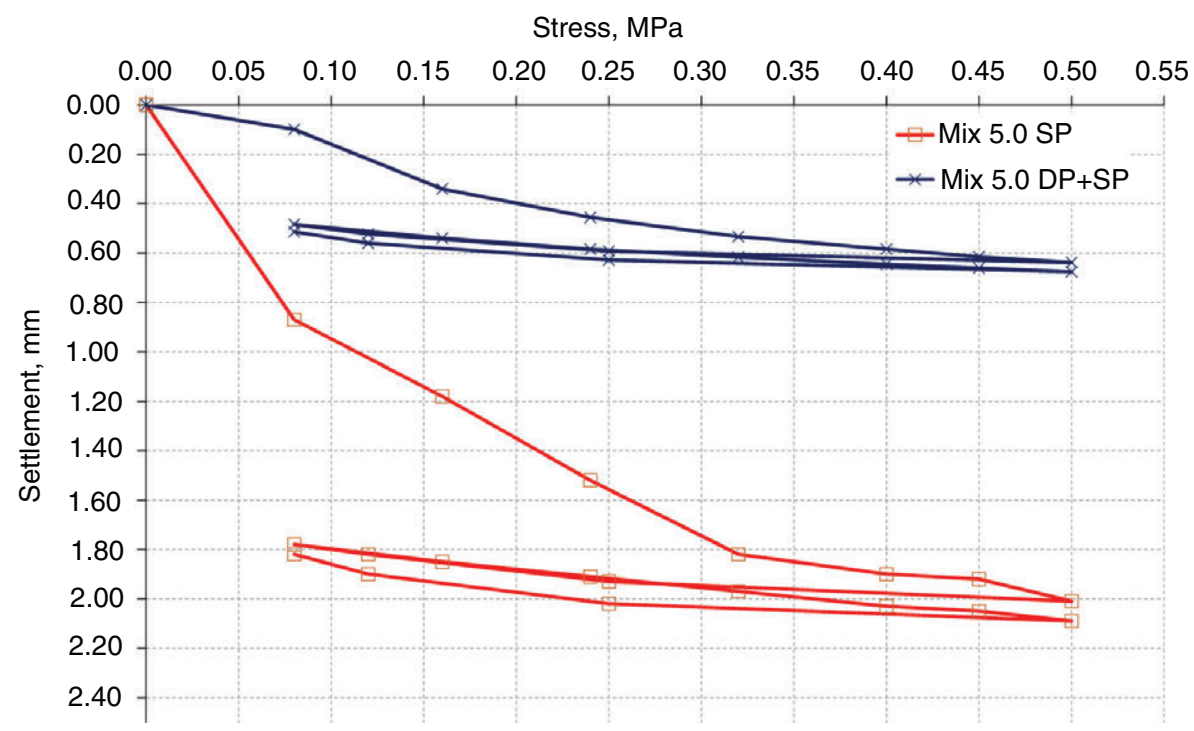

FIGURE 10. Strain-stress curves from the standalone load plate test (SP) and the combination of dynamic and static load plate test $(\mathrm{DP}+\mathrm{SP})$. 
content is shown in Figures 11 and 12. It is worth noting that the addition of rubber particles tends to reduce the bearing capacity, particularly during the second loading step: the $10 \%$ mixture presents a reduction of $20 \%$ in the value of $\mathrm{E}_{\mathrm{v} 1}$ and about $40 \%$ in $\mathrm{E}_{\mathrm{v} 2}$ in comparison with the pattern material.

This is particularly important as PF-7 (8) and UIC 719R (9) both require $\mathrm{E}_{\mathrm{v} 2}$ to be greater than $120 \mathrm{MPa}$. Taking this into account, the appropriate rubber content would be about $2.5 \%$ by weight. However, after applying cyclic loads equivalent to 20 years of service, a content of $5 \%$ would also fulfil the requirements. This aspect requires further research, for instance by measuring the bearing capacity at increasing levels of plastic deformation (e.g. $25 \%, 50 \%, 75 \%$, until reaching $100 \%$ at approximately 100000 cycles as shown in Figure 8).

\subsubsection{Cyclic triaxial test}

The purpose of the cyclic triaxial test was to examine the issue of long-term behaviour. Figure 13 shows the results obtained for each mixture, where

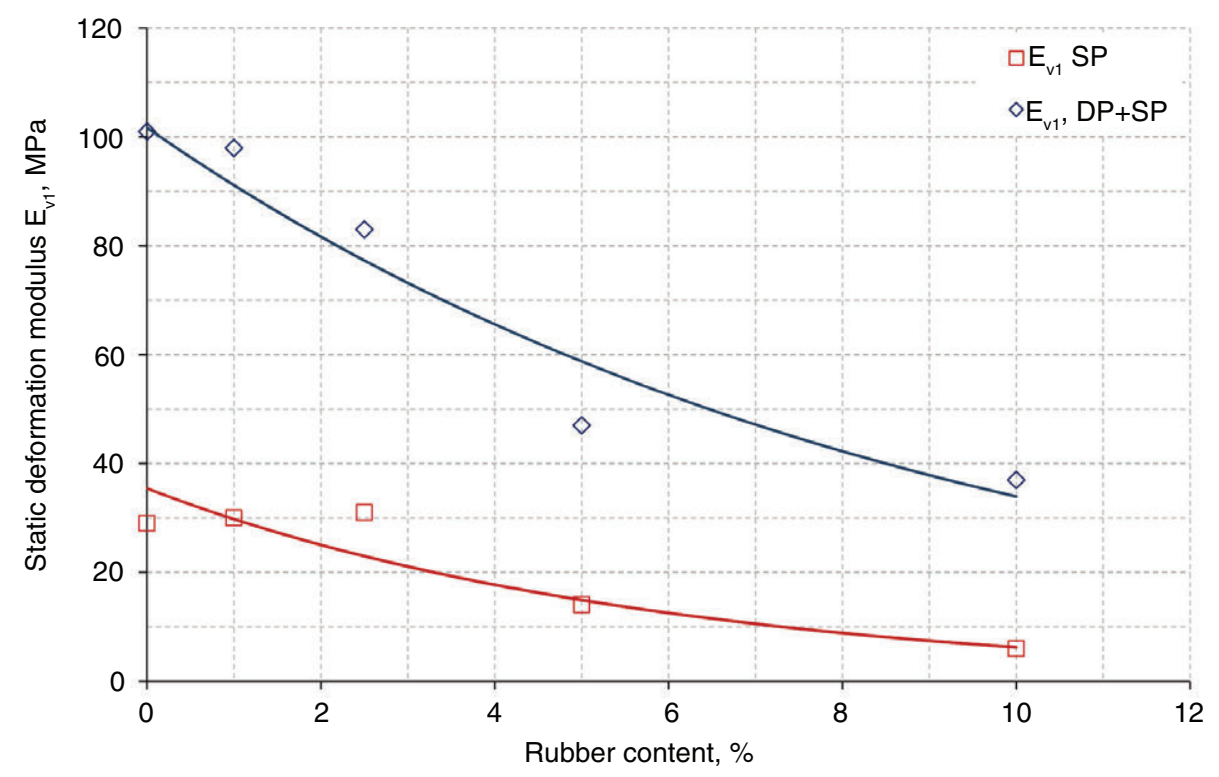

FIGURE 11. Comparison between $\mathrm{E}_{\mathrm{v} 1}$ modulus and rubber content after the static test (SP) and after the combination of static and dynamic test (DP+SP).

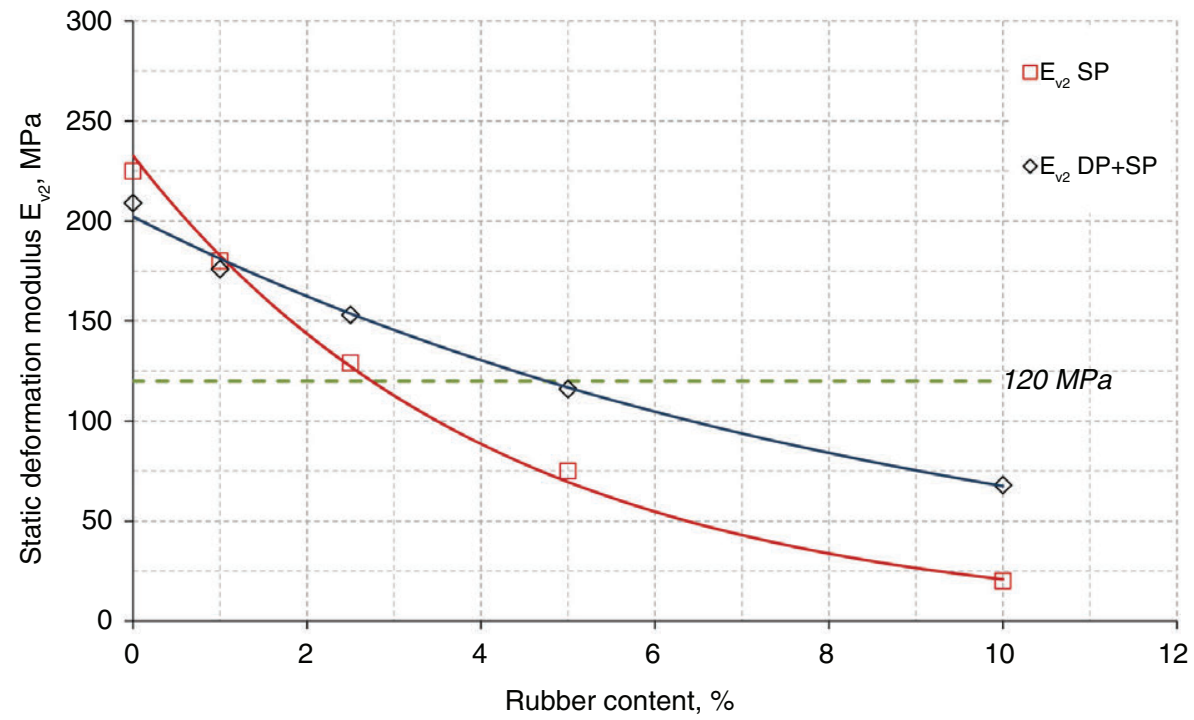

FIGURE 12. Comparison between $\mathrm{E}_{\mathrm{v} 2}$ modulus and rubber content after the static test (SP) and after the combination of static and dynamic tests $(\mathrm{DP}+\mathrm{SP})$ 
each curve defines the plastic creep limit for the corresponding rubber-aggregate mixture.

As the figure shows, the addition of rubber modifies the plastic creep limit and the mixtures with higher rubber content experience plastic creep with lower $\sigma_{1} / \sigma_{3}$ stress levels. Stress levels in sub-ballast layers under railway tracks are usually below $100 \mathrm{kPa}(25)$ with a $\sigma_{1} / \sigma_{3}$ ratio of between three and four (as indicated by the red box in Figure 13). Taking into account these levels, it is clear that an addition of rubber above $2.5 \%$ (by weight) is undesirable as the resultant mixture may experience a combination of stress over the plastic creep limit, and so the sub-ballast layer will be more prone to failure under repeated loading.

As shown in Figure 14, resilient strain (recoverable under repeated loads) also tends to increase with the rubber content. For the same level of stress, all mixtures suffer major post-compaction before the first 100000 cycles (after which permanent strain tends to stabilise). The common trend for all mixtures is that the elastic recovery increases along with rubber content, resulting in a decrease in the resilient modulus when more rubber particles are added (7).

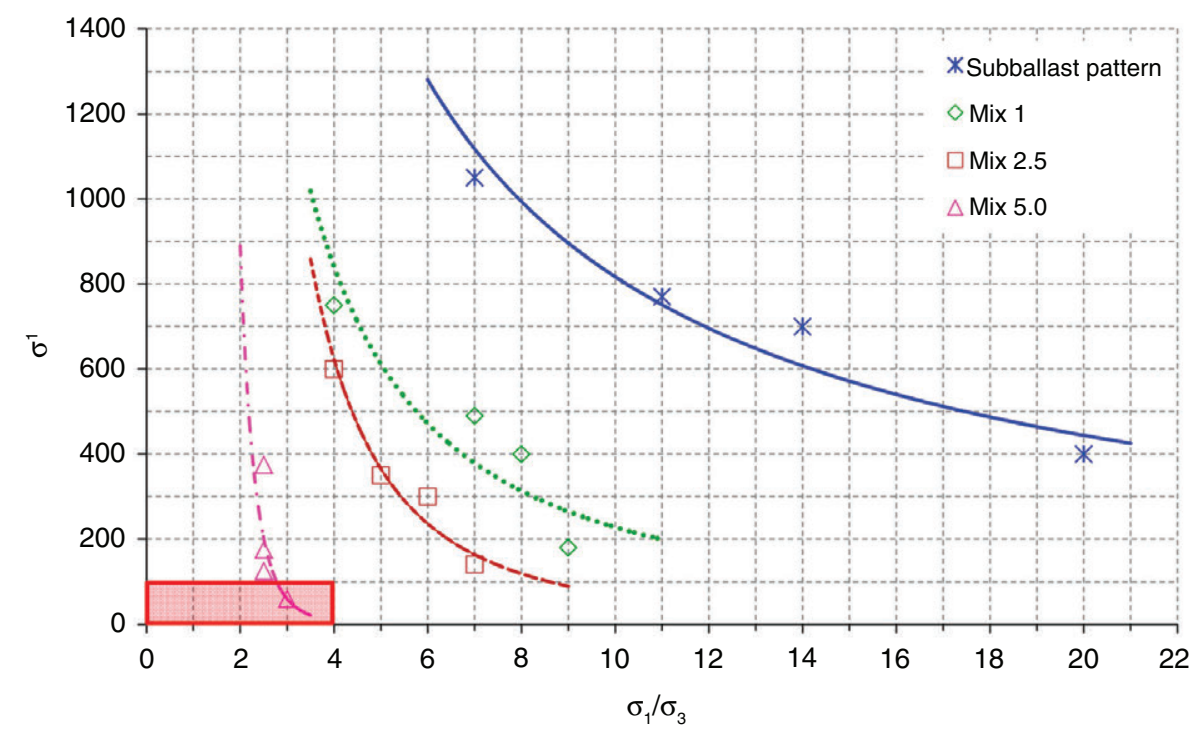

FIGURE 13. Plastic creep limits for each mixture and $\sigma_{1} / \sigma_{3}$ stress ratio. The red box shows the usual stress values in a sub-ballast layer.

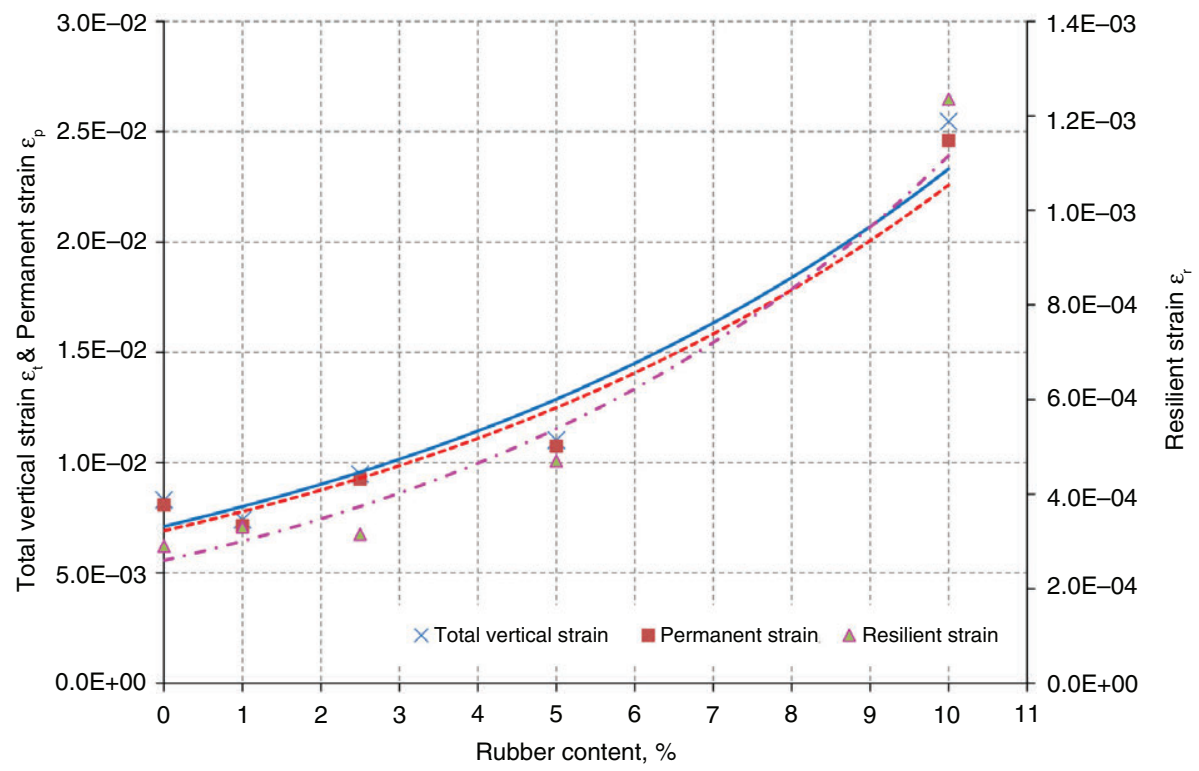

FIGURE 14. Total, permanent, and resilient strains obtained from the dynamic load plate test. 
It is worth noting that both the permanent and resilient strains in the $10 \%$ mixture are about 3.5 to 4 times greater than those of the pattern (comparatively, the growth ratio in the 5\% mixture is about 1.5). This means that once the mixtures are placed beneath the track they will suffer a greater permanent strain than traditional sub-ballast after the first trains pass over. However, once stabilised, these mixtures will also present a greater elastic recovery than conventional aggregate.

\subsubsection{Hydraulic conductivity test}

Table 5 shows the results of the hydraulic conductivity tests carried out according to PF-7 (8). All the mixtures yield a hydraulic conductivity within the same order of magnitude, namely $2.50 \mathrm{E}-5 \mathrm{~m} / \mathrm{s}$, a value similar to the unmixed aggregate and common in uniform gravels with sands and without fine fractions (26). This result shows that adding rubber does not improve hydraulic conductivity because of the bulking induced in the mixture. Therefore, taking into account the conductivity trend observed in Table 5, rubber particles could be added up to $5 \%$ of total weight providing that the aggregate has a hydraulic conductivity below $1 \mathrm{E}-5 \mathrm{~m} / \mathrm{s}$.

\subsection{Field results}

Table 6 shows the results obtained for static plate load and LFWD tests carried out in the experimental platform.

In a similar manner to that which was observed during the laboratory tests, the moduli tend to decrease as the rubber content increases. It is also clear that neither the mixtures, nor the pattern material, present a $\mathrm{K}$ ratio below 2.2 as required by PF-7 (8), and this result was also observed in the

TABLE 5. Hydraulic conductivity vs. rubber content

\begin{tabular}{lc}
\hline Rubber content, $\%$ & Hydraulic conductivity, $\mathbf{K}(\mathbf{m} / \mathbf{s})$ \\
\hline 0 & $1.03 \mathrm{E}-5$ \\
1.0 & $2.30 \mathrm{E}-5$ \\
2.5 & $3.53 \mathrm{E}-5$ \\
5 & $6.26 \mathrm{E}-5$ \\
10 & $2.68 \mathrm{E}-4$ \\
\hline
\end{tabular}

TABLE 6. Static plate load and LFWD tests results

\begin{tabular}{lcccc}
\hline & Pattern & Mix 1.0 & Mix 2.5 & Mix 5.0 \\
\hline $\mathbf{E}_{\mathrm{v} 1}(\mathbf{M P a})$ & 53 & 53 & 51 & 14 \\
$\mathbf{E}_{\mathrm{v} 2}(\mathbf{M P a})$ & 232 & 195 & 160 & 75 \\
$\mathbf{K}=\mathbf{E}_{\mathrm{v} 2} / \mathbf{E}_{\mathrm{v} 1}$ & 4.41 & 3.71 & 3.11 & 5.36 \\
$\mathbf{E}_{\mathrm{vd}}(\mathbf{M P a})$ & 147 & 118 & 75 & 47 \\
$\mathbf{s} / \mathbf{v}$ ratio (average) & 1.85 & 1.78 & 1.93 & 2.79 \\
\hline
\end{tabular}

laboratory (where conditions are more controlled and samples are more carefully compacted (13)).

However, an analogous criterion is used taking into account the results from the LFWD test, which is the $\mathrm{s} / \mathrm{v}$ ratio (i.e. the ratio between the maximum displacement measured 's' and the maximum speed of the loading plate ' $v$ '). This ratio is often used to analyse results from the LFWD and is based on many years of experience in central Europe where the test was developed (27). It is usually assumed that a value greater than 3.5 milliseconds (ms) represents an underachieved compaction. Table 6 show that all samples yield an s/v ratio below $3.5 \mathrm{~ms}$, suggesting that the compacted soil can be further compacted (as the $\mathrm{K}$ values previously obtained from the laboratory tests also show). If the s/v ratio is greater than 3.5 , the soil is unsuitable for further compaction and should be replaced or improved using other techniques to fulfil the regulatory requirements.

An important criterion, as already discussed in Hidalgo et al. (7), is the requirement fixed by the German Railways regulation NGT 39 (28), which establishes that the dynamic modulus $\mathrm{E}_{\mathrm{vd}}$ should be greater than $50 \mathrm{MPa}$. Considering this criterion and the aforementioned criterion related to $\mathrm{E}_{\mathrm{v} 2}$ (which should be greater than $120 \mathrm{MPa}$ ), it is clear that the maximum rubber content to ensure a proper bearing capacity should be about $4 \%$ by weight.

However, these field tests present certain drawbacks as they are rather sensitive to conditions that are not easily controlled in the field, or at least not as controllable as in the laboratory. Therefore, it is interesting to analyse their relationship with the results from laboratory tests. Figure 15 shows a comparison between the second step static deformation modulus $\left(\mathrm{E}_{\mathrm{v} 2}\right)$ measured in the laboratory and the same parameter measured in the field for the four mixtures analysed. The data shows a strong linear correlation between both moduli, a fact that indicates the possibility of estimating the $\mathrm{E}_{\mathrm{v} 2}$ on field using a more controlled laboratory test for this type of rubber-aggregate mixture. Nevertheless, more research is needed to further establish this relationship and obtain a sound correlation formulation.

With regards to the relationship between the dynamic $\left(\mathrm{E}_{\mathrm{vd}}\right)$ and static deformation modulus $\left(\mathrm{E}_{\mathrm{v} 2}\right)$, Figure 16 shows the comparison between both moduli (from field tests). There appears to be a clear linear correlation. Similar results were previously observed for common unmixed aggregate (13). This indicates that the addition of rubber in the range considered (i.e. $5 \%$ or less by weight) does not significantly alter the behaviour of the mineral aggregate and so the same type of correlation between static and dynamic moduli can be studied. 


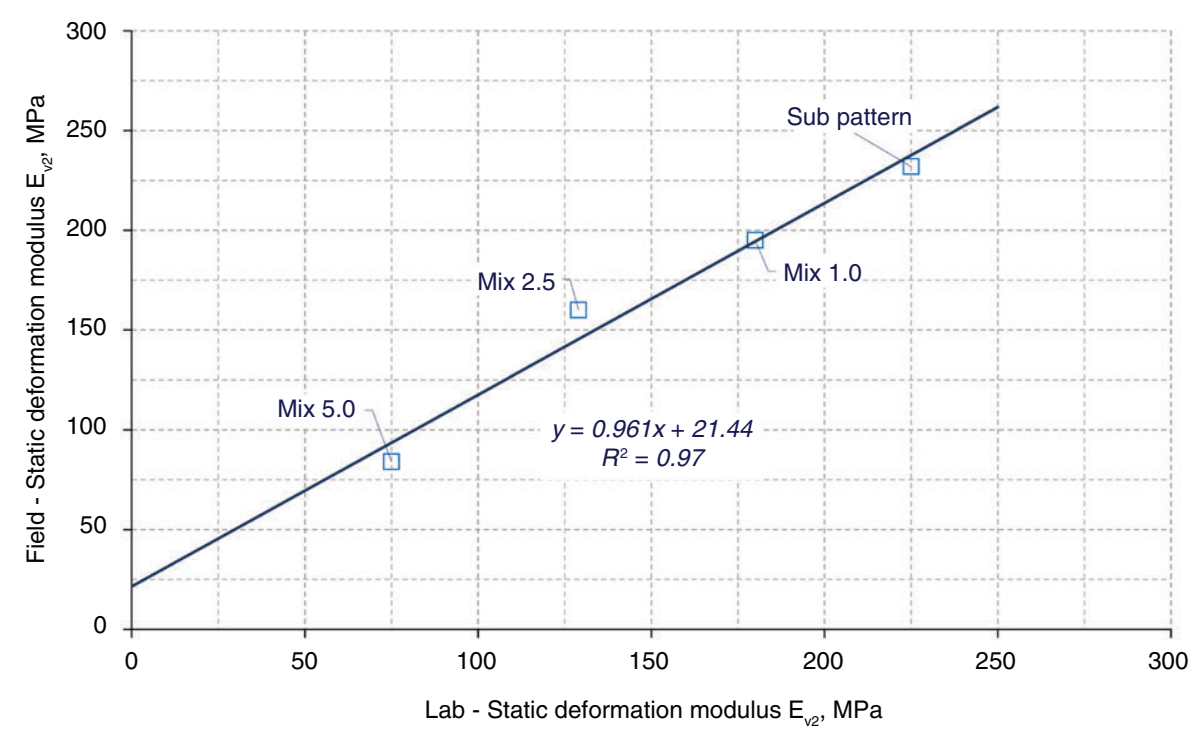

FIGURE 15. Comparison between field and lab static deformation modulus $\mathrm{E}_{\mathrm{v} 2}$.

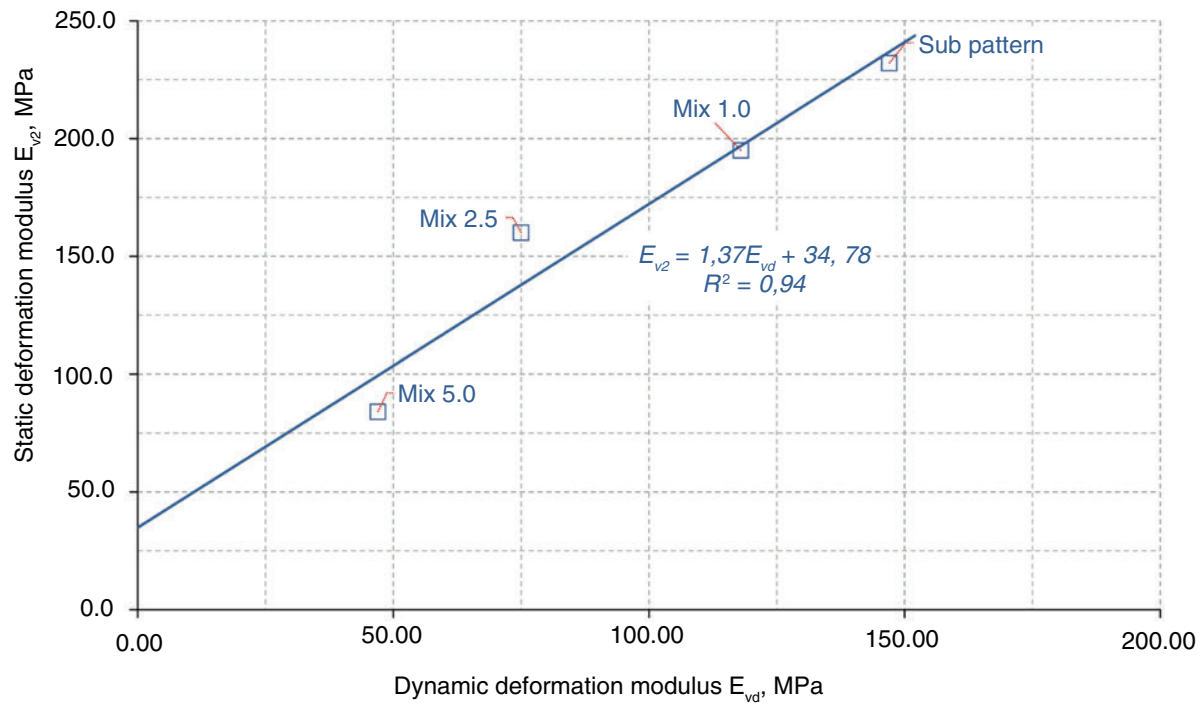

Figure 16. Comparison between field dynamic $\left(\mathrm{E}_{\mathrm{vd}}\right)$ and static $\left(\mathrm{E}_{\mathrm{v} 2}\right)$ deformation modulus.

\section{CONCLUSIONS}

This paper assesses the short and long-term bearing capacity of unbound granular materials mixed with rubber particles from scrap tyres when used as sub-ballast under railway tracks. Four mixtures were prepared with varying rubber contents, namely $1,2.5,5$ and $10 \%$ by weight. These four mixtures, together with an unmixed granular material used as a control sample, were subjected to a series of static load plate tests in the laboratory, as well as a cyclic triaxial test. Specimens were tested following two configurations. The first consisted of standalone load plate test to obtain the static deformation modulus $\mathrm{E}_{\mathrm{v} 1}$ and $\mathrm{E}_{\mathrm{v} 2}$. The second consisted of a dynamic load test followed by a static load test to assess variations in the aforementioned moduli after dynamic compaction. Furthermore, field tests were carried out on an experimental railway platform for comparison with laboratory results.

A series of conclusions can be drawn from the results. Firstly, adding rubber particles to granular sub-ballast reduces the dry density; while the optimum moisture content remains relatively constant (only small variations were observed between mixtures). Moreover, the addition of rubber increases both permanent and resilient strain. All the mixtures studied experienced major post-compaction 
and a progressive collapse during the first 100000 loading cycles, as well as post-compaction increased as the rubber content increased. However, permanent deformation stabilised after 100000 cycles and remained constant for 2.5 million cycles, which is equivalent to some 20 years of life under normal traffic conditions. None of the mixtures showed any sign of plastic creep.

Furthermore, the results from the cyclic triaxial test show that the addition of rubber modifies the plastic creep limit by reducing the stress combination that may lead to failure under repeated cyclic loads. Taking into account the usual stress levels found in sub-ballast layers, mixtures with rubber content greater than $2.5 \%$ may exceed the plastic creep limit, thus becoming more prone to failure.

Considering these results and all the usual criteria required for sub-ballast materials in terms of bearing capacity, the result of adding up to $2.5 \%$ of rubber particles (by weight) complies with the requirements of PF-7 (8) and UIC-719R (9). Adding more rubber may compromise the bearing capacity of the material and long-term stability.

The results obtained from the field tests yield similar conclusions. Considering the usual criterion regarding the dynamic modulus $\left(\mathrm{E}_{\mathrm{vd}}\right)$, rubber content should be limited to $4 \%$. A strong linear relationship was observed between the laboratory and field second step static modulus $\left(\mathrm{E}_{\mathrm{v} 2}\right)$ and between the field static and dynamic moduli $\left(\mathrm{E}_{\mathrm{v} 2} \mathrm{vs}_{\mathrm{vd}}\right)$. Both correlations may help in assessing the bearing capacity of these mixtures when using more controlled laboratory tests, although further research is required to obtain a statistically sound correlation formulation.

As a final conclusion, the results show that adding rubber up to a maximum of $2.5 \%$ by weight yields a material suitable for use as a sub-ballast layer. This may enable recycling large quantities of a problematic waste material and provide a feasible alternative to burning or accumulation in dumping sites.

\section{ACKNOWLEDGEMENTS}

The authors wish to thank GUEROLA for providing the soil samples from its quarry, EMRO for providing the rubber particles, and Elias Medel Perallón and Ángel Morilla Rubio for their help during field tests. Tests were carried out in the Geotechnical Laboratory of the Universidad Politécnica de Valencia.

\section{REFERENCES}

1. Humphrey, D.N.; Blumenthal, M. (2010) The use of tirederived aggregate in road construction applications. Green Streets Highway 2010, 299-313, American Society of Civil Engineers. http://dx.doi.org/10.1061/41148(389)25.

2. Wolfe, S.L.; Humphrey, D.N.; Wetzel, E.A. (2004) Development of tire shred underlayment to reduce groundborne vibration from LRT track. Geotech SP, 750-759.
3. Salgado, R.; Yoon, S.; Siddiki, N.Z. (2003) Construction of tire shreds test embankment. Publication FHWA/IN/JTRP2002/35. Joint Transportation Research Program, Indiana Department of Transportation and Purdue University, West Lafayette, IN. http://dx.doi.org/10.5703/1288284313165.

4. Yoon, S.; Prezzi, M.; Siddiki, N.Z.; Kim, B. (2006) Construction of a test embankment using a sand-tire shred mixture as fill material. Waste Manage. 26 [9], 1033-1044. http://dx.doi.org/10.1016/j.wasman.2005.10.009.

5. Buonanno, A.; Mele, R. (2000) The use of bituminous mix sub-ballast in the Italian State Railways. $2^{\text {nd }}$ Eurasphalt \& Eurobitume Congress, Barcelona, 20-22 September 2000.

6. Sol, M.; Thom, N.H.; Moreno, F.; Rubio, M.C.; Airey, G.D. (2015) A study into the use of crumb rubber in railway ballast. Constr Build Mater. 75, 19-24. http://dx.doi. org/10.1016/j.conbuildmat.2014.10.045

7. Hidalgo, C.; Martínez, P; Medel, E.; Insa, R. (2015) Characterisation of an unbound granular mixture with waste tyre rubber for subballast layers. Mater Struct. 45 [12], 3847-3861. http://dx.doi.org/10.1617/s11527-014-0443-z.

8. PF-7 (2006) Pliego de Prescripciones Técnicas Generales de Materiales Ferroviarios PF-7: Subbalasto (General Technical Specifications for Railway Materials PF-7: Subballast). Spanish Ministry of Public Works and Transport, Madrid. (In Spanish).

9. UIC Code 719R (2008) Earthworks and Track-Bed Layers for Railway Lines. International Union of Railways, Paris.

10. Panadero, C.; Sanz, J.L. (2010) Análisis de las propiedades del sub-balasto: Contradicciones y procesos que afectan a su función (Analysis of sub-ballast properties: Contradictions and processes that affect their performance). Revista Ingeopres 196, 14-21. (In Spanish).

11. BS 1377-9 (1990) Methods for test for soils for civil engineering purposes. In-situ tests: determination of the vertical deformation and strength characteristics of soil by the plate loading. British Standards Institution, London.

12. Santiago, E.; García, J.L.; González, P. (2010) Comparación de diferentes métodos de control de compactación del subbalasto (Comparison of different sub-ballast compaction control methods). CEDEX Geotechnical Laboratory, Madrid. (In Spanish).

13. Seyman, E. (2003) Laboratory evaluation of in-situ tests as potential quality control/quality assurance tools. MSc Thesis, Lousiana State University, Baton Rouge, LA.

14. Tompai, Z. (2008) Conversion between static and dynamic load bearing capacity moduli and introduction of dynamic target values. Period Polytech-Civ. 52 [2], 97-102. http:// dx.doi.org/10.3311/pp.ci.2008-2.06.

15. ASTM D75/D75M-09 (2009) Standard practice for sampling aggregates. American Society for Testing and Materials (ASTM), West Conshohocken, PA.

16. ASTMD1557 (2012) Standard Test Methods for Laboratory Compaction Characteristics of Soil Using Modified Effort $\left(56,000 \mathrm{ft}-\mathrm{lbf} / \mathrm{ft}^{3}\left(2,700 \mathrm{kN}-\mathrm{m} / \mathrm{m}^{3}\right)\right)$ American Society for Testing and Materials (ASTM), West Conshohocken, PA.

17. Melis, M. (2006). Terraplenes y Balasto en Alta Velocidad Ferroviaria (Embankment and ballast in high speed railways). Revista de Obras Públicas 3464, 7-36. (In Spanish).

18. Werkmeister, S.; Dawson, A.R.; Wellner, F. (2005) Permanent Deformation Behaviour of Granular Materials. Road Mater Pavement. 6 [1], 31-51. http://dx.doi.org/10.10 80/14680629.2005.9689998.

19. Cerni, G.; Cardone, F.; Virgili, A.; Camilli, S. (2012) Characterisation of permanent deformation behaviour of unbound granular materials under repeated triaxial loading. Constr Build Mater. 28 [1], 79-87. http://dx.doi. org/10.1016/j.conbuildmat.2011.07.066

20. UNE-EN 13286-7 (2008) Unbound and hydraulically bound mixtures - Part 7: Cyclic load triaxial test for unbound mixtures. Spanish Association for Normalization and Certification (AENOR), Madrid.

21. ASTM E2835 (2011) Standard Test Method for Measuring Deflections using a Portable Impulse Plate Load Test Device. American Society for Testing and Materials (ASTM), West Conshohocken, PA. 
22. UNE 103807-2 (2008) Plate loading test of soils by means of dynamic plate. Part 2: Rigid plate, diameter $2 \mathrm{r}=300 \mathrm{~mm}$, Method 2. Spanish Association for Normalization and Certification (AENOR), Madrid.

23. Speir, R.H.; Witczak, M.W. (1996) Use of shredded rubber in unbound granular flexible pavement layers. Transp Res Record. 1547, 96-106. http://dx.doi.org/10.3141/1547-14.

24. Santamarina, J.C.; Klein, K.A.; Fam, M.A. (2001) Soils and Waves. Particulate Materials. Behavior, Characterization and Process Monitoring. John Wiley \& Sons Ltd., Baffins Lane, Chichester.

25. Peña, M. (2003) Tramos de ensayo de vía en placa en la línea del corredor del Mediterráneo para su explotación a alta velocidad (Slab track test sites in the Mediterranean Corridor for high speed use). Revista de Obras Públicas 3431, 57-68. (In Spanish).
26. Cecich, V.; Gonzales, L.; Hoisaeter, A.; Williams, J; Reddy, K. (1996) Use of shredded tires as lightweight backfill material for retaining structures. Waste Manage Res. 14, 433-451. http://dx.doi.org/10.1006/ wmre.1996.0043.

27. Weingart, W. (1993) Einbaukontrolle mit dem Leichten Fallgewichtsgerät auf Tragschichten ohne Bindemittel - Arbeitsweise des Prüfgerätes, Erfahrungen bei seinem Einsatz (Control of unbound granular materials layers by the Light Drop-Weight Tester - Testing and experience of its use). Mineralstofftagung - Conference on Minerals, Nuremberg, 1993. (In German).

28. NGT 39 (1997) Richtlinie für die Anwendung des Leichten Fallgewichtsgerätes im Eisenbahnbau (Application of Light Drop-Weight Tester in Railways). German Railways. (In German). 